\title{
Development, bromatological and sensory analysis of biscuit prepared on apple flour
}

\section{(Malus communis)}

\author{
Desenvolvimento, análise bromatológica e sensorial de biscoito elaborado a base de farinha de maçã \\ (Malus communis)
}

Desarrolo, análisis bromatológico y sensorial de galletas producidas con harina de manzana (Malus

communis)

\author{
Ana Carolina Sebastião Serra \\ ORCID: https://orcid.org/0000-0001-5408-501X \\ Universidade Católica Dom Bosco, Brasil \\ E-mail: anacarolinasebastiaoserra@gmail.com \\ Nicole dos Santos Vilela de Souza \\ ORCID: https://orcid.org/0000-0001-5998-4030 \\ Universidade Católica Dom Bosco, Brasil \\ E-mail: nicollevilela1@gmail.com \\ Déborah Aparecida Bulde de Oliveira \\ ORCID: https://orcid.org/0000-0002-9030-1522 \\ Universidade Católica Dom Bosco, Brasil \\ E-mail: deborah.bulde@gmail.com \\ Laura Beatriz da Silva \\ ORCID: https://orcid.org/0000-0002-8094-6781 \\ Universidade Católica Dom Bosco, Brasil \\ E-mail: laura.bya.silva@gmail.com \\ Lilliam May Grespan Estodutto da Silva \\ ORCID: https://orcid.org/0000-0001-7264-2617 \\ Universidade Católica Dom Bosco, Brasil \\ E-mail: lmaygrespan@gmail.com
}

\begin{abstract}
The consumption of fiberis extrmely important, as its ingestion helps prevent diseases and regulate bowel function, so there is great interest ftom the food industry in the development of new products based on dietary fiber. The objetive of the present work was to elaborate and evaluate the acceptance of cookies made from apple flour. The study was carried out at the Biosaúde laboratory of the Don Bosco Catholic University, in Campo Grande - MS. The flour was prepared from apples from the same batch, dehydrated and crushed. In the cookies formulation, $45 \%$ of apple flour was used,which made up its base. The evaluation of the components and their quantity were carried out through chemical analysis, obtaining means and standard deviation. The sensory evaluation had 30 untrained judges, in which two tests were used during the research: the hedonic scale and the attitude or purchase intention scale. The results obtained presented an innovative cookies with apple flour, this one had a great response of acceptability index $(85,08 \%)$, standing out in the purchase intentions. Through the data obtained, it is concluded that the product obtained can be commercially included under the sensory point of view, in addition to presenting an excellent nutritional profile, aiming at the treatment and prevention of diseases such as diabetes, dyslipidemia and intestinal disorders.
\end{abstract}

Keywords: Functional foods; Disorders; Innovation.

\section{Resumo}

O consumo de fibras é de extrema importância, pois a sua ingestão ajuda evitar doenças e regular o funcionamento intestinal, assim há um grande interesse da indústria de alimentos no desenvolvimento de novos produtos à base de fibras alimentares. O objetivo do presente trabalho foi elaborar e avaliar a aceitação de biscoito produzido à base de farinha de maçã. O estudo foi realizado no Laboratório BioSaúde da Universidade Católica Dom Bosco, em Campo Grande - MS. A farinha foi preparada a partir de maçãs do mesmo lote, desidratadas e trituradas. Na formulação dos biscoitos foi utilizada $45 \%$ de farinha de maçã, o que compôs sua base. A avaliação dos componentes e quantidade dos mesmos foram realizadas através de análises bromatológicas, obtendo médias e desvio padrão. A avaliação sensorial contou com 30 julgadores não treinados, na qual foram utilizados dois testes durante a pesquisa: a escala hedônica e a escala de atitude ou intenção de compra. Os resultados obtidos apresentaram um biscoito inovador com farinha de maçã, este teve uma ótima resposta de índice de aceitabilidade $(85,06 \%)$, destacando-se nas intenções de compra. Através dos dados alcançados conclui-se que o produto obtido pode ser incluso comercialmente sob o ponto de vista sensorial, além 
de apresentar um ótimo perfil nutricional, visando o tratamento e prevenção de doenças como diabetes, dislipidemias e distúrbios intestinais.

Palavras-chave: Alimentos funcionais; Distúrbios; Inovação.

\section{Resumen}

El consumo de fibras es de sumamente importante, ya que su ingestión ayuda a prevenir enfermedades y regular la función intestinal, por lo que existe un gran interés de la industria alimentaria en el desarrollo de nuevos productos basados en fibra dietética. El objetivo del presente trabajo fue elaborar y evaluar la aceptación de galletas producidas a base de harina de manzana. El estudio se realizó en el Laboratorio BioSaúde de la Universidad Católica Don Bosco, en Campo Grande - MS. La harina se preparó a partir de manzanas del mismo lote, se deshidrató y se trituró. En la formulación de galletas se utilizó un $45 \%$ de harina de manzana, que componía su base. La evaluación de los componentes y su cantidad se realizó mediante análisis químico, obteniendo medias y desviación estándar. La evaluación sensorial incluyó a 30 jueces no capacitados, en los que se utilizaron dos pruebas durante la investigación: la escala hedónica y la escala de actitud o intención de compra. Los resultados obtenidos presentaron una galleta innovadora con harina de manzana, ésta tuvo una excelente respuesta de índice de aceptabilidad (85,06\%), destacándose en las intenciones de compra. Mediante de los datos obtenidos, se concluye que el producto obtenido puede ser incluido comercialmente bajo el punto de vista sensorial, además de presentar un excelente perfil nutricional, orientado al tratamiento y prevención de enfermedades como diabetes, dislipidemias y trastornos intestinales.

Palabras clave: Alimentos funcionales; Disturbios; Innovación.

\section{Introduction}

Fruit waste and losses occur at all stages of the production chain, thus generated by a large amount of waste and caused a large environmental and economic impact (Lima et al., 2018). There are several ways to make use of these fruits, one of them is the production of flours, which can be used in various recipes, because they are rich in nutrients such as fibers, minerals and vitamins (Fontes et al., 2014; Henríquez, 2010).

With the increase in agricultural production, there is a good part of the fruits, such as apples, which are not marketed in natura, thus they are destined for industrialization. This expansion of planting areas generates apples of low commercial value for consumption because of various defects, such as stains, imperfections, undesirable size and inadequate coloration. Thus, the industry uses the advance of production to support the stabilization of trade, granted in the off-season, the product destined to industry not only in the manufacturing areas, but also in the regions that do not produce them (Danesi et al., 2007).

The fibers can be classified into two types, soluble (FAS) and insoluble (FAI), according to their solubility in water. FAI increase the production of fecal bolus and decrease intestinal transit time in the large intestine, thus being widely used in the treatment of constipation. FAS, on the other hand, have as characteristic the formation of viscous gels and are not digested in the small intestine, thus being fermented by bacteria of the large intestine, and the FAI are not gel-forming and are fermented limited by the bacteria of the large intestine (Bernaud \& Rodrigues, 2013).

According to Guarino (2020) the intake of fibers in daily feeding is directly connected with the prevention of diseases, especially cancer, in addition, explains that for the treatment of constipation, FAI perform the increase of fecal cake, decrease the cycle of intestinal transit and eliminate feces more easily and quickly.

Thus, it is possible to notice that these fibers used in functional foods have a great importance, such as apple flour that is rich in both soluble and insoluble fibers and act in the stimulation of intestinal flora, promoted better quality of life of individuals avoided those problems related to intestinal disorders grow. (Aune et al, 2011; Bingham et al, 2003).

These disorders have a negative impact on the quality of life of individuals, because in addition to generating discomfort, they cause economic expenses. Among the main symptoms we can mention: abdominal pain or discomfort, bloating, altered bowel habit and borborygmus that is known for "snoring in the belly" (Spiller \& Thompson, 2012).

By having of the observed aspects, the importance of the present work is due to the elaboration of apple flour, as an ingredient in the production of biscuits, in order to nutritionally aggregate the formulation, reuse and also evaluate its acceptability by the consumer. 


\section{Materials and methods}

\subsection{Raw material}

The apples used for flour manufacturing and biscuit analysis were Fuji type (Malus communis) acquired in local trade and all had the same batch. They were selected, avoided any type of injury or alterations and maintained the same size of preference.

\subsection{Flour preparation}

The apples $(20 \mathrm{Kg})$ were previously washed with running water to remove visible dirt and soon after, they were submitted to a solution of sodium hypochlorite at $5 \%$ for 15 minutes for disinfection, after the second washing with running water for the removal of the product.

After being washed and dried, the seeds and peduncle were removed, the apples were cut into thin slices and arranged in steel trays, covered with parchment paper, and were taken to the greenhouse with forced air circulation at a temperature of $60^{\circ} \mathrm{C}$ for 22 hours. After the drying process, the apples were crushed in a domestic processor and then passed in a sieve to remove small lumps that still exist, thus obtaining uniformity of the flour $(1.5 \mathrm{~kg})$, as expressed in Figure 1.

The flour was packed in glass pots with threading lids and were kept in a dark cabinet to avoid contact with light and water resorption until it was used for the manufacture of the biscuit.

Figure 1 - Flowchart of apple flour production for the preparation of biscuits.

$20 \mathrm{Kg}$ of apples sanitized with sodium hypochlorite $5 \%$

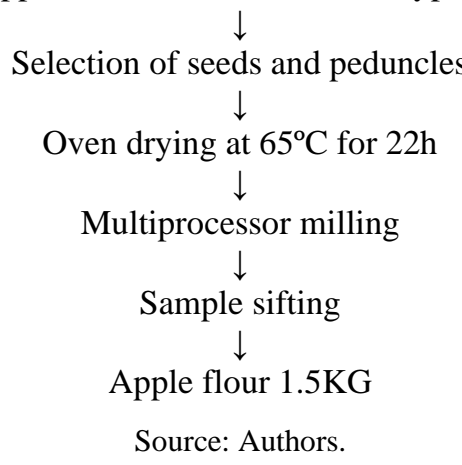

\subsection{Biscuit preparation}

The biscuit was prepared from $45 \%$ apple flour, $55 \%$ of the biscuit was composed of other ingredients presented in Table 1.

Table 1. Quantities of ingredients for the formulation of biscuits made with $45 \%$ apple flour.

\begin{tabular}{ll}
\hline Makings & Quantities $(\mathbf{g})$ \\
\hline Apple flour & 187,50 \\
Oat meal & 93,75 \\
Egg & 51,30 \\
Margarine & 56,25 \\
Chocolate drops half bitter & 23,00 \\
Baking powder & 6,56 \\
\hline
\end{tabular}


The formulation was prepared in a common way, where the egg and margarine were placed in a container and beaten together until full homogenization, soon after apple flour, oat meal was added, until it gave the correct point and the dough was no longer stuck in the hands. And finally, the chocolate drops half bitter and the baking powder were added. Then biscuit formats were made and the dough was baked in a preheated oven for 15 minutes at $180^{\circ} \mathrm{C}$.

\subsection{Bromatological analysis}

The preparation of the sample to be analyzed was performed from the baked and crushed biscuit.

Humidity was determined by the drying method. Since this is a gravimetric procedure, a process that isolates its component to its purest form, in which the loss by desiccation occurs in an oven at $105^{\circ} \mathrm{C}$ until constant weight. The determination of ash was made from an also gravimetric method, in which the total destruction of the organic matter present in the sample occurs (AOAC, 2000).

For protein, the amount of nitrogen was determined by the Micro-Kjeldahl method - neutralization titulometry and the results were converted to crude protein with application of conversion factor 6.25 (AOAC, 2000). Lipids were determined from the Goldfish device extraction method, which is characterized by a continuous process, which obtains the lipid fraction present in the raw material to be used in the system. This process is carried out with solid samples and hot solvents are used, with the reflux of the solvent for oil extraction (Instituto Adolfo Lutz, 2008).

To determine the carbohydrate content, the Lane-Eynon method was performed using the Fehling reagent (AOAC, 2000). And at the end, the determination of fibers was performed by calculating the difference in $100 \%$.

All determinations were made in triplicates and then the means of the values were made. The results obtained were presented in percentage form and in tables.

\subsection{Sensory analysis of apple flour biscuit.}

After the approval of the Research Ethics Committee (CEP) with the term of acceptance of the CAAE number 4394821.0.0000.5162, the sensory analyses were performed through the tasting of the biscuit prepared on the basis of apple flour, 30 untrained tasters were selected, including employees and students of the university itself, during working hours and their study, in which they were invited to do the analysis, where it took place at the Food Technology Laboratory of the Catholic University Don Bosco - UCDB.

All of them received the Free and Informed Consent Form (TCLE), in which they signed an agreed to participate in the sensory analysis. With this, they received the product together with the evaluation form contained a questionnaire with the following points: aroma, flavor and texture, listed from 9 to 1 to describe how much they liked or disliked the product presented. In addition, the intention to purchase the product was also evaluated, in which there were options: it would certainly not buy, possibly would not buy, possibly buy the product and would certainly buy the product.

\subsection{Acceptability index}

The acceptability index (AI) of each preparation was analyzed according to the following expression: A $(\%)=\mathrm{A} \times 100 /$ $\mathrm{B}$, where $\mathrm{A}$ is the average score obtained by the product and B is the maximum score given to the product (Teixeira et al, 1987).

\subsection{Methodologicals uporte for research} (2018).

The data presented followed the protocols of teaching, research and scientific methodology, as described by Estrela 


\subsection{Data analysis}

The data were presented in a described way, the variables absolute frequencies (n), relative frequency in percentage $(\%)$, and numerical variables were presented. The results were arranged in tables and graphs.

\section{Results and Discussion}

In this work, Fuji apple flour (Malus communis) and biscuit preparation with $45 \%$ of the apple flour concentration were elaborated, and from these were performed the bromatological analysis and sensory evaluation of the biscuit. The results presented below were obtained after flour crushing, as described in Table 2.

Table 2. Bromatological analysis of Fuji apple flour (Malus communis).

\begin{tabular}{ll}
\hline Nutrients (\%) & Apple Flour \\
\hline Ashes & $1.94 \pm 0.02$ \\
Moisture & $33.43 \pm 0.32$ \\
Proteins & $1.17 \pm 0.71$ \\
Lipids & $0.54 \pm 0.05$ \\
Carbohydrates & $60.84 \pm 2.89$ \\
Fibers & $2.08 \pm 2.07$ \\
\hline
\end{tabular}

Values expressed with mean \pm standard deviation. Source: Authors (2021).

Moisture is one of the most important parameters for the stability of flours during storage. According to the results obtained, apple flour presented moisture of 33.31\%, a value above what is defined by Resolution RDC n 263 of September 2005 (Brasil, 2005), where the specific moisture requirements for flours should be a maximum of $15 \%$.

The ash content in food aims to indicate the amount of inorganic or mineral residue (Zambiazi, 2010). The value found of ash in apple flour was $1.94 \%$, which is due to the contribution of minerals such as calcium, magnesium and potassium, present in the apple, this value found is considered slightly lower than the content found in the study by Scheeren (2012) where the ash content was $2.86 \%$.

The value found for proteins in apple flour was 1.17\%, according to a study carried out by Córdova (2006), the protein contents present in apple are relatively low, as most of the enzymes are involved in the metabolism of the fruit during development, maturation and post-harvest. Regarding the lipid content, the value of $0.54 \%$, was found, according to Córdova (2006), the lipid content is only associated with the protective layer of the cells and the epidermis of the fruits.

According to Coelho and Wosiacki (2010) the constituents with the highest content are carbohydrates, since about 75\% are sugars easily assimilated by man. The values of the present study in relation to carbohydrate content were $60.84 \%$, being considered low compared to the content found by Scheeren (2012) of $75.21 \%$ in apples, it is important to highlight that the recipe used by the author may have altered the result he obtained in his studies.

Regarding the fiber content, the value of $2.08 \%$ was found, it was also possible to identify a value similar to this in the Brazilian Table of Food Composition - TBCA (TBCA, 2020) of 2.03\%. The chemical composition of the biscuits at $45 \%$ of apple flour is presented in Table 3. 
Table 3. Bromatological analysis of biscuit prepared with $45 \%$ Fuji apple flour (Malus communis).

\begin{tabular}{ll}
\hline Parameter (\%) & Apple biscuit formulation \\
\hline Ashes & $1.35 \pm 0.01$ \\
Moisture & $30.10 \pm 0.25$ \\
Proteins & $5.92 \pm 0.09$ \\
Lipids & $12.60 \pm 0.38$ \\
Carbohydrates & $37.68 \pm 3.89$ \\
Fibers & $12.35 \pm 5.08$ \\
\hline
\end{tabular}

Values expressed with mean \pm standard deviation. Source: Authors (2021).

Higher moisture and carbohydrate contents were verified in the bromatological analysis, which is explained by the fact that, according to Franco (2014), apples contain about 80\% water, $10 \%$ of total sugars and a considerable portion of dietary fibers (2-3\%), in addition, the presence of oats contributes to these nutrients being highlighted, for being a food of excellent nutritional value and rich in fiber (Terra, 2019).

The value of food fibers of the biscuit based on $45 \%$ of apple flour is 12.35 , which is explained according to the Brazilian Table of Food Composition - TACO where, the amount of food fibers of the apple is 1.3 grams (TACO, 2011). In addition, the presence of oatmeal was extremely important for it to obtain such a result, because the food is rich in this component, made the prevention of diseases, treatment of constipation and others are increasingly avoided, in addition to increasing the fecal cake and eliminating feces more easily.

It can be observed that proteins present a value of 5.92\%, in which much of the influence of oats and egg used in the recipe, where protein sources are important, can also be considered. What justifies table 2, which shows the contents of pure apple flour the value of the same nutrient is $1.71 \%$. In the study of Terra (2019) it mentions that the quality of oat proteins stands out, varied between $12.40 \%$ to $24.50 \%$, in the peeled grain.

The lipid index (12.60\%) is explained by the presence of margarine, oats and egg. To explain this, Galvão et al. (2017) shows in his study that egg has low fat content, had in the lipid percentage higher concentrations of fatty acids established. The total lipid content of the egg is only $11 \%$ of its weight, which is not very high. The study presents 30 to $34 \%$ lipids in the yolk and 0.1 to $0.2 \%$ of lipids in the clear (Galvão et al., 2017). For the manufacture of biscuits, an entire egg was used. Oats, on the other hand, are a cereal of nutritional value of excellence, thus providing a significant contribution to a balanced energy and nutritional supply. Its lipid content is 3.1 to $10.9 \%$ according to Borges (2006). In addition, the author mentions that the consumption of oatmeal is extremely beneficial for human health, as it is rich in fiber, aided in reducing blood cholesterol and glucose levels. It can also contribute to technological, sensory, nutritional and functional properties, making moisture absorbed and delight food aging.

Margarine, since it is an ingredient based on a water-like emulsion in oil containing approximately $80 \%$ lipids (Nunes, 2019), increased the total lipid content present in the biscuit composition.

In the present study, the sensory analysis was performed using a group of untrained judges composed of 17 female and 13 male tasters, constituting a percentage of $56.6 \%$ and $43.3 \%$, respectively.

According to Table 4, the attribute that presented the best acceptance was taste, with $86.6 \%$ of average acceptability. 
Table 4. Sensory analysis of the biscuit prepared with $45 \%$ Fuji apple flour (Malus communis).

\begin{tabular}{lll}
\hline Attributes & Biscuit at 45\% with average (SD) & AI (\%) \\
\hline Aroma & $7.60 \pm 1.16$ & 84,44 \\
Texture & $7.50 \pm 1.31$ & 83,33 \\
Flavor & $7.80 \pm 0.97$ & 86,66 \\
Global Acceptance & $7.65 \pm 0.87$ & 85,00 \\
\hline
\end{tabular}

Values expressed with mean \pm standard deviation (SD) and acceptability index (AI). Source: Authors (2021).

The texture attribute presented a slightly lower average than the acceptance with $83.3 \%$ differentiated from the other attributes. The average acceptability of the aroma attribute was $84.4 \%$. In comparison to the study conducted by Fontes (2014) it was possible to identify values approximate to the aroma $81.1 \%$ and flavor $83.6 \%$, already with regard to texture, the present study presented an average of $83.3 \%$ was higher than the average presented of $68.4 \%$.

The overall impression attribute of the apple flour biscuit was 85\%, according to Pinto (2010), so that a product is commercially approved, it is essential that the acceptability rate exceeds $70 \%$. In this way, the formulation of apple flour biscuit can be considered commercially accepted.

The apple flour biscuits presented a good acceptability by the judges in all attributes, as shown in the Figure 2.

Figure 2. Scale of purchase intention of untrained judges.

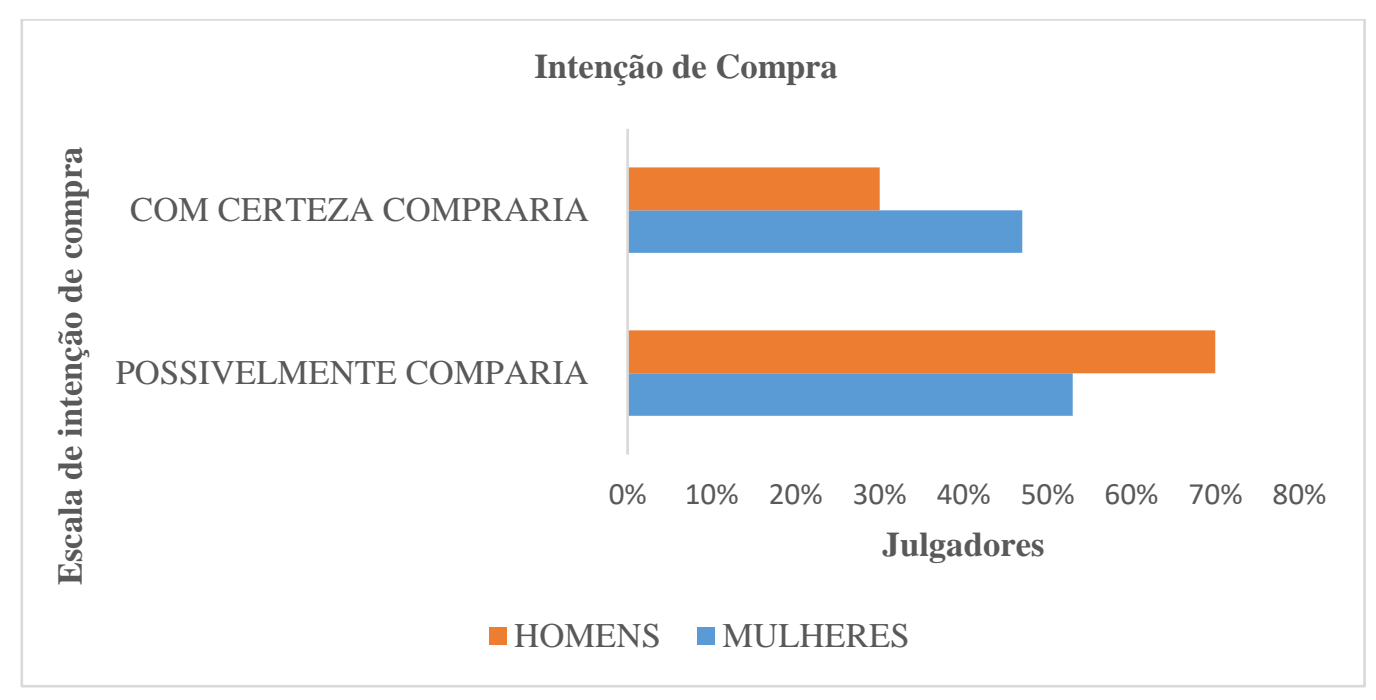

Source: Authors (2021).

The votes in the evaluation form with the hedonic terms would surely buy and possibly buy between women and men were $52.94 \%$ and $47.05 \%$ (women) and $69.23 \%$ and $30.76 \%$ (men) respectively. The values obtained in the acceptance tests by attributes suggest that the product had good acceptance presented the acceptability index (AI) of $85.06 \%$ and may be included commercially by the consumer from the sensory point of view.

\section{Conclusion}

The product showed good acceptance among the judges, since a large part of the evaluators approved the product and presented a great acceptabilility index (AI) which could be commercialy included by the consumer from the sensory point of view. Based on the bromatological analysis of the biscuit, it was possible to identify a Nutritional prolife rich in fiber that can be used in diets with the aim of preventing diseases such as diabetes, dyslipidemia and intestinal disordrs. The production of cookies with apple flour can become na alternative for the elaboration of a healthier diet. 


\section{References}

AOAC. (2002). Métodos Oficiais de Análise da AOAC International. (17th ed.), Associação de Químicos Analíticos Oficiais (AOAC).

Aune, D., Chan, D. S. M., Lau, R., Vieira, R., Greenwood, D. C., Kampman, E., \& Norat, T. (2011). Dietary fibre, whole grains, and risk of colorectal cancer: systematic review and dose-response meta-analysis of prospective studies, British Medical Journal, $10(343)$, d6617.

Borges, J. T. S., Pirozi, M. R., Lucia, S. M. D., Pereira, P. C., Moraes, A. R. F., \& Castro, V. C. (2006). Utilização de farinha mista de aveia e trigo na elaboração de bolos. Boletim do centro de Pesquisa de Processamento de Alimentos, 24(1), 145-162.

Brasil (2005). Ministério da Saúde, Agência Nacional de Vigilância Sanitária. Resolução nº 263, de 22 de setembro de 2005 . Fixa a identidade e as características mínimas de qualidade a que devem obedecer aos Produtos de Cereais, Amidos, Farinhas e Farelos. Exclui-se deste Regulamento a Farinha Desengordurada de Soja. Diário Oficial da União. 2005. https://bvsms.saude.gov.br/bvs/saudelegis/anvisa/2005/rdc0263_22_09_2005.html.

Bernaud, F. S. R., \& Rodrigues, T. C. (2013). Dietary fiber: adequate intake and effects on metabolism health. Arquivos Brasileiros de Endocrinologia \& Metabologia, 57(6), 397-405.

Bingham, A. S., Day, N. E., Luben, R., Ferrari, P., Slimani, N., Norat, T., Clavel-Chapelon, F., Kesse, E., Nieters, A., Boeing, H., Tjonneland, A., Overvad, K., Martinez, C., Dorronsoro, M., Gonzalez, C. A., Key, T. J., Trichopoulou, A., Naska, A., Vineis, P., Tumino, R., Krogh, V., Bueno-de Mesquita, H. B., Peeters, P. H. M., Berglund, G., Hallmans, G., Lund, E., Skeie, G., Kaaks., \& Riboli, E. (2003). Dietary fibre in food and protection against colorectal cancer in the European Prospective Investigation into Cancer and Nutrition (EPIC): an observational study. Lancet, 3, 361(9368), $1496-501$.

Coelho, L. M., \& Wosiacki, G. (2010). Avaliação sensorial de produtos panificados com adição de farinha de bagaço de maçã. Ciência e Tecnologia de Alimentos, $30(3), 582-588$

Córdova, K. R. V. (2006). Desidratação osmótica e secagem convectiva de maçã Fuji comercial e industrial [Dissertação de mestrado, Universidade Federal do Paraná].

Danesi, E. D. G., Fukuji, T. S., Alves, G. L. A., Oliveira, R. C. G., Lino, M. C., \& Praça, V. A. (2007). Avaliação da influência da casca no processamento de sucos clarificados de maçãs Fuji e Fuji. Acta Scientiarum. Technology, 29(1), 91-97.

Estrela, C. (2018). Metodologia Científica: Ciência, Ensino, Pesquisa. Editora Artes Médicas, (3a ed).

Fontes, V. S., Moreira, R. V., Campos, P. P., \& Fialho, C. G. O. (2014). Desenvolvimento de biscoitos enriquecidos com farinha de maçã e aveia. HU Revista, 40(3e4), 231-238.

Franco, P. M. L. (2014). Características físico-químicas, propriedades funcionais e perfil de compostos fenólicos de 17 variedades de maçãs portuguesas. [Tese doutorado, Faculdade de Ciências e Tecnologia, Universidade Nova Lisboa].

Galvão, J. A., Possebon, F. S., Spina, T. L. B., Guerra Filho, J. B. P., Santos, G. C., Pantoja, J. C. F., \& Pinto, J. P. A. N. (2017). Diferenças nas características físicas de ovos produzidos sob pastejo livre e sistema convencional. Archives of Veterinary Science, 22(4), 52-61.

Guarino, M. P. L., Altomare, A., Emerenziani, S., Di Rosa, C., Ribolsi, M., Balestrieri, P., Iovino, P., Rocchi, G., \& Cicala, M. (2020). Mechanisms of action of prebiotics and their effects on gastrointestinal disorders in adults. Nutrients, 12(4), 1037-1061.

Instituto Adolfo Luttz. (2008). Normas Analíticas do Instituto Adolfo Lutz. Métodos físico-químicos para análises de alimentos, (4a ed).

Henríquez, C., Speisky, H., Chiffelle, I., Valenzuela, T., Araya, M., Simpson, R., \& Almonacid, R. (2010). Development of an ingredient containing apple peel, as a source of polyphenols and dietary fiber. Journal of Food Science, 75(6), H172-181.

Lima, D. S., Duarte, N. B. A., Barreto, D. L. C., Oliveira, G. P., Takahashi, J. Ap., Fabrini, S. P., \& Sande, D. (2018). Passion fruit and apple: from residues to antioxidante, antimicrobial and anti-Alzheimer's potential. Ciência Rural, 48(9),1-4.

Nunes, C. A., Magalhães, K. T., Haddad, F. F., \& Silva, G. C. (2020). Óleo de amêndoa de macaúba tem potencial com ingrediente lipídico em margarina e maionese. Revista Agrarian, 13(47),122-129.

Pinto, D., Silva, N. A. V., Batista, V. M., Vieira, A. G., Souza, G., Dumont, C. R., Santos, P. V., \& Marques, G. K. (2010). Características físico-químicas da amêndoa de macaúba e seu aproveitamento na elaboração de barras de cereais. Alimentos e Nutrição, 21(1),79-86.

Scheeren, P., Lehn, N. D., \& Souza, C. F. (2012). Aproveitamento de maçãs não conformes à comercialização na elaboração de pães. Revista Destaque Acadêmicos, 4(4), 68-75.

Spiller, R. C., \& Thompson, G. (2012). Transtornos intestinais. Arquivos de Gastroenterologia, 49(1),1-3.

Tabela brasileira de composição de alimentos (TACO). (2011). (4a ed). NEPA UNICAMP.

Tabela Brasileira de Composição de Alimentos. TBCA. (2020). Universidade de São Paulo (USP). Food Research Center (FoRC). (versão 7.1).

Teixeira, E., Meinert, E. M., \& Barbetta., P. A. (1987). Análise sensorial de alimentos. UFSC.

Terra, D. A. (2019). Composição e propriedades fisiológicas e funcionais da aveia. FAG Journal of health, 1(2),186-200.

Zambiazi, R. C. (2010). Análise Físico Química de Alimentos. SAS Institute. System for Information. (versão 8.0). Editora Universitária/UFPEL. 